\title{
Exposure to Bacterial Products Renders Macrophages Highly Susceptible to T-Tropic HIV-1
}

\author{
Masako Moriuchi, ${ }^{\star \ddagger}$ Hiroyuki Moriuchi, ${ }^{\star}$ Willie Turner, ${ }^{\ddagger}$ and Anthony S. Fauci ${ }^{\star}$ \\ *Laboratory of Immunoregulation, National Institute of Allergy and Infectious Diseases, National Institutes of Health, Bethesda, \\ Maryland 20892; and ${ }^{\ddagger}$ Department of Microbiology, Howard University College of Medicine, Washington, D.C. 20059
}

\begin{abstract}
Microbial coinfections variably influence HIV-1 infection through immune activation or direct interaction of microorganisms with HIV-1 or its target cells. In this study, we investigated whether exposure of macrophages to bacterial products impacts the susceptibility of these cells to HIV-1 of different cellular tropisms.

We demonstrate that (1) macrophages exposed to bacterial cell wall components such as lipopolysaccharide (LPS) (Gram-negative rods), lipoteichoic acid (Gram-positive cocci), and lipoarabinomannan (Mycobacteria) become highly susceptible to T cell (T)-tropic HIV-1 (which otherwise poorly replicate in macrophages) and variably susceptible to macrophage (M)-tropic HIV-1; (2) LPS-stimulated macrophages secrete a number of soluble factors (i.e., chemokines, interferon, and proinflammatory cytokines) that variably affect HIV infection of macrophages, depending on the virus phenotype in question; and (3) LPS-stimulated macrophages express CCR5 (a major coreceptor for M-tropic HIV-1) at lower levels and CXCR4 (a major coreceptor for T-tropic HIV-1) at higher levels compared with unstimulated macrophages.

We hypothesize that a more favorable environment for T-tropic HIV-1 and a less favorable or even unfavorable environment for M-tropic HIV-1 secondary to exposure of macrophages to those bacterial products may accerelate a transition from M- to T-tropic viral phenotype, which is indicative of disease progression. (J. Clin. Invest. 1998. 102: 1540-1550.) Key words: lipopolysaccharide • lipoteichoic acid • lipoarabinomannan $\cdot$ chemokines $\cdot$ chemokine receptors
\end{abstract}

\section{Introduction}

Infection with HIV is characterized by biphasic bursts of early and late viremia (1). The first burst of viral replication occurs within weeks after primary infection. This peak of viremia is

M. Moriuchi and H. Moriuchi contributed equally to this project, which M.M. performed for the partial fulfillment of the Ph.D. program of the Department of Microbiology at Howard University, Washington, D.C.

Address correspondence to $\mathrm{H}$. Moriuchi, NIH, Building 10, Room 6A11, Bethesda, MD 20892. Phone: 301-402-2617; FAX: 301402-4122; E-mail: hmoriuchi@atlas.niaid.nih.gov

Received for publication 1 June 1998 and accepted in revised form 21 August 1998.

The Journal of Clinical Investigation

Volume 102, Number 8, October 1998, 1540-1550

http://www.jci.org generally markedly downregulated over a period of weeks by the host cellular and humoral immune response; however, the virus almost invariably escapes from complete immune containment, resulting in a state of chronic, persistent infection. Eventually, profound immune deficiency caused by the infection leads to dramatically enhanced levels of viral replication, susceptibility to and development of opportunistic infections and malignancies, AIDS, and death (1). The source of the high levels of viremia at the advanced stage of HIV disease has remained somewhat of a paradox because at this stage lymphoid tissue is highly disrupted and $\mathrm{CD}^{+} \mathrm{T}$ cells are markedly depleted. A recent study, however, has indicated that tissue macrophages are a major source of HIV during opportunistic infections at advanced stages of HIV disease (2).

The ability of HIV to infect different types of cells varies from isolate to isolate and is referred to as cellular tropism (35). All strains of HIV infect primary $\mathrm{CD}^{+} \mathrm{T}$ cells. HIV strains isolated during primary infection and the clinically latent period of disease are also able to infect and replicate in macrophages but not in established $\mathrm{CD}^{+} \mathrm{T}$ cell lines. These strains of HIV-1 are classified as macrophage (M) tropic. As HIV disease progresses, the virus tends to extend its host cell range and often acquires the capability to infect and replicate in established $\mathrm{CD}^{+} \mathrm{T}$ cell lines (6). These strains of virus are referred to as T cell (T) tropic, and typically, are unable to infect and replicate in macrophages; however, many of the clinical isolates from patients with advanced stage disease are dual tropic and retain the capability of infecting both $\mathrm{T}$ cell lines and macrophages to variable degrees (6). Surprisingly, only M-tropic viruses are thought to be able to establish a primary infection. This hypothesis is based upon studies of vertical or sexual transmission of HIV in humans where it has been shown that M-tropic viruses were selectively transmitted (7-10). These observations suggest that viral, host and/or environmental factors involved in cellular tropism, especially macrophage tropism, of HIV influence the efficiency of viral transmission, as well as the levels of viral replication and the transition from M-tropic to T-tropic phenotype during the natural course of infection.

Beyond the characteristic biphasic early and late peaks in viral replication, intermittent bursts of increased viremia also have been identified in HIV-infected patients. The aforemen-

1. Abbreviations used in this paper: $\mathrm{AMV}$, amphotropic murine leukemia virus; Ara-LAM, noncapped lipoarabinomannan; LAM, lipoarabinomannan; LTA, lipoteichoic acid; Man-LAM, mannose-capped lipoarabinomannan; MDM, monocyte-derived macrophages; MOI, multiplicity of infection; $\mathrm{M}$ tropic, macrophage tropic; PE, phycoerythrin; PIK, phosphatidylinositol 3-kinase; PKC, protein kinase C; PL, phospholipase; PTK, protein tyrosine kinase; RT, reverse transcriptase; rVV, recombinant vaccinia virus; SACE, Staphylococcus aureus crude extracts. 
tioned events have been shown to be associated with episodes involving immune stimulation caused by vaccination and opportunistic infections involving bacterial, viral, or parasitic microbes (reviewed in reference 11). Immune stimulation also is associated with the induction of a diverse range of cytokines that modulate HIV infection positively or negatively (reviewed in reference 1 ).

The ability of various microbial pathogens or their products to directly affect HIV replication in vitro has been reported. Dual infection of individual cells with HIV-1 and herpes viruses (12-14) or human T-lymphotropic virus type I (15) resulted in enhanced expression of HIV. Similarly, HIVinfected cells that were superinfected with or exposed to products of Mycobacterium tuberculosis (16) and Toxoplasma gondii (17) showed a significantly enhanced expression of HIV. These latter studies have been strengthened by the observation that macrophages are the major source of HIV during certain opportunistic infections (2) and that the major cellular targets for these microbial pathogens are macrophages $(2,16,17)$. In addition, several studies have shown that the Gram-negative bacterial cell wall constituent, LPS, enhanced HIV replication in monocytoid cell lines $(18,19)$; however, other studies have reported the induction of resistance of macrophages to HIV infection upon LPS stimulation (20-22). Such a discrepancy could have resulted from differences in methods used for macrophage propagation or in virus strains used in the experiments. In this regard, it would be important to determine the role of various bacterial components, such as Gram-positive bacterial cell wall components and lipoarabinomannan (LAM) of mycobacteria, in the modulation of HIV infection both in vitro and in vivo since these infections are common in HIVinfected individuals and are generally curable or preventable.

In this study, we demonstrate that macrophages exposed to certain bacterial products become highly susceptible to T-tropic HIV-1 (which otherwise poorly replicate in macrophages) and modestly susceptible to M-tropic HIV-1 and that LPS-stimulated macrophages secrete a number of soluble factors (i.e., chemokines, interferon, and proinflammatory cytokines) that variably affect HIV infection of macrophages, depending on the virus phenotype in question. In addition, we demonstrate the LPS-stimulated macrophages express CCR5 (a major coreceptor for M-tropic HIV-1 [23-27]) at a lower level and CXCR4 (a major coreceptor for T-tropic HIV-1 [28]) at a higher level compared with unstimulated macrophages. This dichotomy of a more favorable environment for T-tropic HIV-1 and a less favorable or even unfavorable environment for M-tropic HIV-1 may accerelate the transition from M-tropic to T-tropic HIV phenotype, which is indicative of disease progression $(6,29,30)$.

\section{Methods}

Cells. Monocyte-derived macrophages (MDM) were propagated as described previously (31) and allowed to differentiate for $7 \mathrm{~d}$ in DMEM supplemented with $10 \%$ heat-inactivated human serum (HS) derived from male type AB blood (Sigma Chemical Co., St. Louis, $\mathrm{MO})$ in the presence or absence of the indicated concentration of LPS. Typically, $>96 \%$ of the cells were macrophages as determined by morphology and cytochemical staining for nonspecific esterase (Sigma Chemical Co.).

$H I V-1$ strains and propagation of HIV-1 stocks. The following molecular clones were used in viral infection assays: NL4-3 (laboratoryadapted T tropic [32]), ELI1 (primary T tropic [33]), 89.6 (dual tropic
[34]), and ADA8 (M tropic [35]). Virus stocks were propagated by transfecting $293 \mathrm{~T}$ cells with plasmids encoding the respective molecular clones, as described previously (36).

Experimental infection of MDM. Approximately $2 \times 10^{5} \mathrm{MDM}$ were infected with the molecular clone stocks mentioned above at an approximate multiplicity of infection (MOI) of 0.05 . In some experiments, the cells were treated with the indicated conditioned medium for $1 \mathrm{~h}$ before and throughout infection. After 3-6 $\mathrm{h}$ incubation at $37^{\circ} \mathrm{C}$, the cells were extensively washed to remove unabsorbed virus, refed with fresh medium, and approximately half of each infected cell culture supernatant was replaced with the same medium every $4 \mathrm{~d}$; the collected supernatants were kept at $-20^{\circ} \mathrm{C}$ for subsequent reverse transcriptase (RT) assays as described previously (31).

Single-round virus replication assay. NL4-3-Luc- $\mathrm{R}^{-} \mathrm{E}^{-}$virus stocks pseudotyped by various Envs were generated by transfecting $293 \mathrm{~T}$ cells with pNL4-3-Luc- ${ }^{-} \mathrm{E}^{-}$(25) and with plasmids expressing Env from either HXB2 (laboratory adapted, T tropic [25]), ELI1 (primary T tropic), 89.6 (dual tropic [24]), ADA (M tropic [24]), or amphotropic murine leukemia virus (AMV [25]), as described previously (25). Approximately $2 \times 10^{5}$ MDMs were infected with the various virus stocks $\left(5 \times 10^{5} \mathrm{cpm} \mathrm{RT}\right.$ activity) carrying the luciferase reporter gene. Where indicated, cells were treated with the indicated conditioned medium $1 \mathrm{~h}$ before and throughout infection. Infected cell lysates were assayed for luciferase activity as described previously (36).

Recombinant vaccinic viruses and fusion assays. The following recombinant vaccinic virus (rVV) stocks were kindly provided by E. Berger (National Institute of Allergy and Infectious Diseases) and used in fusion assays: vTF7-3 (expressing T7 RNA polymerase), vCB21R (encoding the lac $Z$ gene under the control of the T7 promoter), vCB16 (expressing a mutant form of HIV-1 IIIB Env that is unable to be cleaved into gp120 and gp41), vSC60 (expressing HIV-1 T-tropic IIIB Env), and vCB43 (expressing M-tropic HIV-1 Ba-L Env). rVV-based cell fusion assays were performed as described previously $(28,36)$. In brief, MDMs (fusion targets) were infected with vTF7-3 (expressing the T7 RNA promoter) at an MOI of 10; as fusion effectors, BSC-1 cells (which are known not to express any HIV coreceptor [28]) were infected with vCB21R (encoding the lacZ gene under the control of the T7 promoter) as well as rVV expressing the mutant HIV Env (vCB16), wild-type IIIB (T tropic) Env (vCB41), or Ba-L (M tropic) Env (vCB43) at an MOI of 10 each. Cells were incubated at $31^{\circ} \mathrm{C}$ overnight, and both fusion targets $\left(5 \times 10^{5} \mathrm{MDMs}\right.$ per well $)$ and fusion effectors $\left(1 \times 10^{5}\right.$ BSC- 1 cells per well $)$ were mixed in 96-well flat-bottom microtiter plates in the presence of $40 \mu \mathrm{g} / \mathrm{ml}$ of cytosine arabinoside. The mixed cell lysates were assayed for $\beta$-galactosidase activity.

Preparation of LPS-conditioned medium. Crude supernatants from MDM cultures either unstimulated or stimulated with LPS $(1 \mu \mathrm{g} / \mathrm{ml})$ for $7 \mathrm{~d}$ were clarified by low-speed centrifugation $(3,000 \mathrm{rpm}, 30 \mathrm{~min})$ and filtered through $0.2-\mu \mathrm{m}$ filters to remove cells. Supernatant $(1 \mathrm{ml}$ per aliquot) was incubated with either mouse IgG isotype control, monoclonal anti-IFN- $\alpha$ antibody $(20 \mu \mathrm{g})$, or a mixture of monoclonal antibodies to RANTES, MIP- $1 \alpha$, and MIP- $1 \beta$ ( $20 \mu \mathrm{g}$ each) at $4^{\circ} \mathrm{C}$ for $2 \mathrm{~h}$, followed by incubation with protein $\mathrm{A} / \mathrm{G}$ sepharose (UltraLink Immobilized Protein A/G; Pierce Chemical Co., Rockford, IL) at $4^{\circ} \mathrm{C}$ overnight. Immune complexes bound on the sepharose were removed by extensive washing.

ELISA. The concentration of IFN- $\alpha$ in the supernatants was determined by an ELISA kit provided by Endogen Inc. (Woburn, MA), and those of other cytokines were determined by ELISA kits provided by R\&D Systems Inc. (Minneapolis, MN).

Reagents. LPS from Salmonella minnesota and phenol extracts of Staphylococcus aureus suspensions, containing some polysaccharides and other soluble components of the cell as well as lipoteichoic acid (37), and referred to as $S$. aureus crude extracts (SACE), were purchased from Sigma Chemical Co. Mannose-capped lipoarabinomannnan (Man-LAM) from M. tuberculosis and noncapped LAM (Ara-LAM) from a rapid growing Mycobacterium sp. were kindly provided by J.T. Belisle (Colorado State University, Fort Collins, 
CO). LPS contamination of SACE, Man-LAM, or Ara-LAM was $<10 \mathrm{ng}$ per $1.0 \mathrm{mg}$ for each reagent.

Anti-human CD14 monoclonal antibody (MY4) was purchased from Coulter Corp. (Miami, FL) and dialyzed to remove azide. Neutralizing monoclonal antibodies to RANTES, MIP- $1 \alpha$, or MIP-1 $\beta$ were purchased from R\&D Systems, and neutralizing anti-IFN- $\alpha$ were obtained from Endogen. Recombinant human RANTES, MIP$1 \alpha$, MIP-1 $\beta$, IL-1ra, soluble TNF receptors 1 and 2 (sTNFR1 and sTNFR2) were purchased from R\&D Systems, and IFN- $\alpha$ were obtained from Endogen. 1-(5-isoquinolinesulfonyl)-2-methylpiperazine (H-7), staurosporine, $N$-(2-guanidinoethyl)-5-isoquinolinesulfonamide (HA-1004), herbimycin A, genistein, and wortmannin were purchased from Sigma Chemical Co.

Flow cytometry. Antibodies used for flow cytometry were the following: FITC-conjugated anti-human CCR5 monoclonal antibody 2D7 (PharMingen, San Diego, CA), phycoerythrin (PE)-conjugated anti-human CXCR4 monoclonal antibody 12G5 (PharMingen), PEconjugated anti-human CD14 (Becton-Dickinson Immunocytometry Systems, San Jose, CA), and mouse immunoglobulin G isotype controls (Becton-Dickinson Immunocytometry Systems). Approximately $2 \times 10^{5}$ cells were preincubated with PBS supplemented with $5 \% \mathrm{HS}$ and $0.04 \%$ sodium azide to reduce nonspecific binding for 15 min on ice, stained with the indicated antibodies for $1 \mathrm{~h}$ on ice in the dark, washed, fixed with $1 \%$ paraformaldehyde, and analyzed on a Cell Quest apparatus (Becton-Dickinson Immunocytometry Systems).

Transient expression assays. Plasmids pGL-RANTES, pGL-CCR5, and pGL-CXCR4 are luciferase reporter constructs for the promoter regions of RANTES, CCR5, and CXCR4, respectively (38-40). Blood monocytes were plated on $60-\mathrm{mm}$ diameter tissue culture plates, and 3-5 d later, the cells were transfected with the above-mentioned plasmids by a modified calcium phosphate method (41). The transfected cell lysates were tested for luciferase activity $3 \mathrm{~d}$ later, as described above.

\section{Results}

LPS stimulation of macrophages markedly enhances replication of T-tropic HIV-1 but has minimal effect on replication of $M$-tropic $H I V$-1. There has been considerable controversy concerning whether primary macrophages support replication of T-tropic HIV-1. Certain studies reported the inability of T-tropic strains of HIV-1 to efficiently replicate in primary macrophages (42-44), while others reported that macrophages supported replication of several T-tropic viruses $(45,46)$. Furthermore, a recent study demonstrated that macrophages are a major source of HIV-1 during opportunistic infections in the advanced stage of HIV disease (2). Since CD4 ${ }^{+} \mathrm{T}$ cell numbers in individuals in the advanced stages of HIV disease are markedly decreased and in some cases unmeasurable and at the same time many HIV-1 variants isolated from those individuals are T-tropic, the question of the ability of macrophages to support replication of these viral phenotypes arises.

We therefore hypothesized that macrophages might be capable of supporting replication of T-tropic HIV-1 under the conditions seen in individuals with opportunistic infections. In this regard, MDM were infected with HIV and stimulated with microbial products such as LPS, to which macrophages are exposed during conventional or opportunistic infections. To clarify whether different virus strains used in previous studies (42-46) might have given rise to seemingly conflicting data, we infected MDM with infectious molecular clones that possessed different biological features, including laboratory-adapted T-tropic strain NL4-3, primary T-tropic strain ELI1, dualtropic strain 89.6, and M-tropic strain ADA8.
All HIV-1 strains were able to infect unstimulated MDM; however, as expected, M-tropic ADA8 virus and dual-tropic 89.6 virus replicated relatively well, while infection with T-tropic NL4-3 and ELI1 viruses was quite muted (Fig. $1 A$ ). Of note, MDM became fully permissive to the T-tropic viruses after $7 \mathrm{~d}$ of LPS stimulation; levels of virus production, determined by RT activity, were increased by 10 -fold or more (Fig. $1 A$ ). LPS stimulation also enhanced replication of dual-tropic 89.6 virus by threefold but had only a modest effect on M-tropic ADA8 infection (Fig. $1 A$ ); in some experiments, LPS stimulation actually suppressed replication of ADA8 virus (data not shown).

Marked increase in susceptibility to T-tropic HIV-1 infection was also observed in LPS-stimulated MDM with the homozygous CCR5 mutation, while M-tropic ADA8 virus did not replicate in these cells (Fig. $1 B$ ). Therefore, LPS effects on T-tropic HIV-1 are not dependent on the normal expression of the CCR5 coreceptor.

Bacterial cell wall components from Gram-positive cocci or mycobacteria enhance HIV-1 replication in macrophages. We next tested whether exposure to constituents from other types of bacteria also influences infectability of HIV-1 in MDM. SACE (constituents of Gram-positive cocci) and Ara-LAM (constituents of less virulent Mycobacteria), similar to LPS, are capable of activating macrophages, while Man-LAM (constituents of virulent Mycobacteria) does not induce macrophage activation $(37,47,48)$.

When stimulated with SACE or Ara-LAM, MDM allowed efficient replication of T-tropic (Fig. 2) or dual-tropic (data not shown) HIV-1. In contrast, Man-LAM had no or very little effect on HIV-1 infection of MDM. None of these bacterial components markedly influenced replication of M-tropic HIV-1, except that a modest increase in replication of M-tropic HIV-1 in macrophages stimulated with Ara-LAM was inconsistently observed (data not shown). Thus, components of a diverse group of bacterial pathogens, Gram-negative bacilli (LPS), Gram-positive cocci (SACE), or Mycobacteria (LAM) have similar effects on HIV-1 infection of macrophages in a virus strain-dependent manner.

Stimulation with bacterial cell wall components mediates its effects on HIV replication via CD14, protein kinase $C$, and protein tyrosine kinase. CD14 is a receptor used by mammalian cells to recognize and signal responses to a diverse array of bacterial constituents, such as LPS, SACE, and LAM (49), and several signaling pathways have been shown to be involved in LPS responses (reviewed in reference 50). One of the major consequences of LPS stimulation is expression and secretion of proinflammatory cytokines such as TNF- $\alpha$ and IL-1 $\beta$, which are known to enhance HIV-1 replication (reviewed in reference 51).

To investigate the cellular and molecular events involved in LPS-mediated effects on HIV-1 replication in macrophages, we used inhibitors of CD14 or of proinflammatory cytokines. First, we blocked CD14-LPS interaction by pretreating cells with anti-CD14 mAb MY4. This mAb has been shown to efficiently bind to CD14 and block a variety of LPS-induced effects; however, LPS concentrations $>10 \mathrm{ng} / \mathrm{ml}$ overcome the blocking effect of the mAb (52-54). Pretreatment of MDM with MY4 markedly inhibited the LPS-mediated effect on T-tropic ELI1 virus replication, while isotype control $\mathrm{Ab}$ had no blocking activity (Fig. $3 \mathrm{~A}$ ). Similar results were obtained for effects mediated by SACE or Ara-LAM (data not shown). 


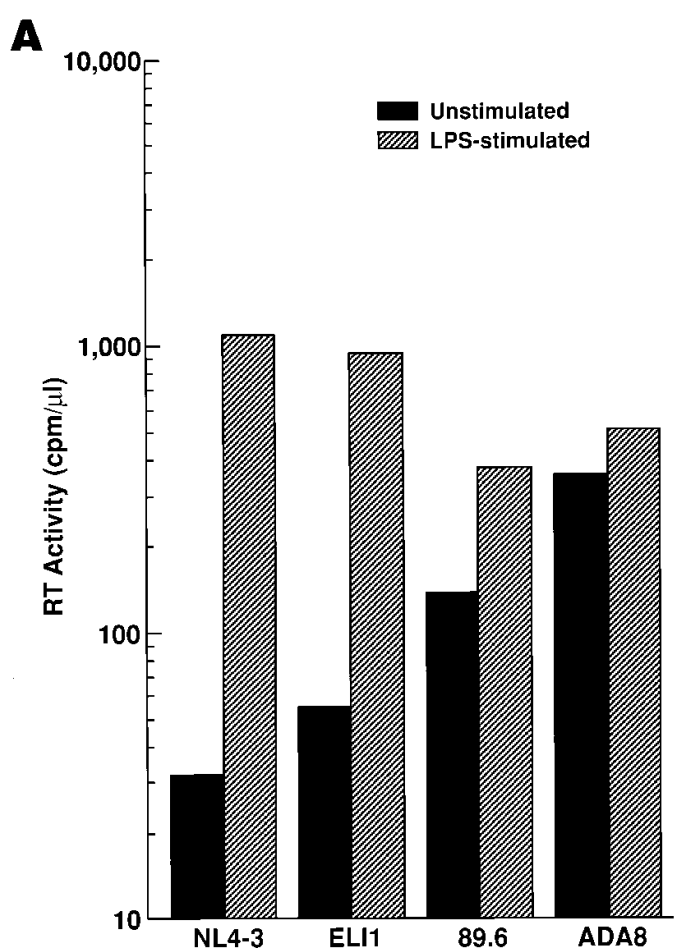

B

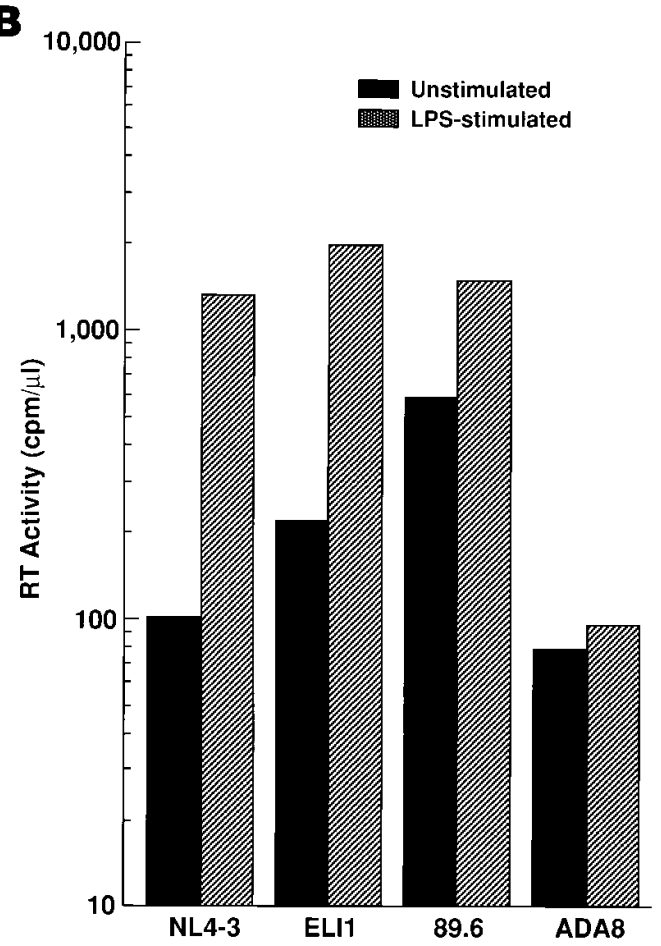

Figure 1. HIV-1 replication in LPS-stimulated macrophages. ( $A$ ) Freshly isolated monocytes were either unstimulated or stimulated with LPS (10 $\mathrm{ng} / \mathrm{ml}$ ) for $7 \mathrm{~d}$ and infected with the indicated molecular clones. The infected culture supernatants were collected every $4 \mathrm{~d}$ for RT assays. Peak titers on day 12 postinfection are shown. Background RT titer in this experiment was $40 \mathrm{cpm} /$ $\mu l$ or less. Results are representative of four independent experiments. (B) MDM derived from the CCR5- $\Delta 32$ homozygotes were propagated and infected as described above. Peak titers on day 12 postinfection were shown. Background RT titer in this experiment was $120 \mathrm{cpm} / \mu \mathrm{l}$ or less. Similar results were obtained from two other CCR5- $\Delta 32$ homozygotes.
We next investigated which CD14 signaling pathways are involved in LPS-mediated effects on HIV-1 replication. To determine whether protein tyrosine kinases (PTKs) are involved in LPS-mediated effects on HIV-1 replication in macrophages, two specific inhibitors of PTK, herbimycin A and genistein, were used. Previous reports have demonstrated that these inhibitors are effective against most tyrosine kinases but have no effect on cyclic nucleotide-dependent protein kinases, protein kinase $\mathrm{C}$ (PKC), phosphorylase kinase, or phospholipase (PL) $\mathrm{C}$ or $\mathrm{D}(55,56)$. In contrast, $\mathrm{H}-7$ and staurosporine inhibit PKC activity, and to lesser extent, cyclic nucleotide-dependent protein kinase activity (57), while wortmannin is an inhibitor of phosphatidylinositol 3-kinase (PIK) and PLD (58) and HA1004 is an inhibitor of cyclic nucleotide-dependent protein kinases, PKA and PKG (57). Freshly isolated monocytes were treated with the indicated reagents for $2 \mathrm{~h}$ before LPS treatment, allowed to differentiate into macrophages, and infected with T-tropic ELI1 strain. As shown in Fig. 3 B, the LPS-mediated effect on viral replication in MDM was virtually abolished by $\mathrm{H}-7$ (a PKC inhibitor) and herbimycin $\mathrm{A}$ and genistein (PTK inhibitors) and reduced substantially by staurosporine (a PKC inhibitor); neither HA-1004 (a PKA/PKG inhibitor) nor wortmannin (a PIK/PLD inhibitor) had an effect (Fig. $3 \mathrm{~B}$ ). These results suggest that PKC and PTK activities are involved in LPS-mediated effects on HIV-1 replication in macrophages.

PKC and PTK activities are critical for LPS-induced TNF- $\alpha$ and IL-1 $\beta$ production by macrophages (59), and these proinflammatory cytokines are potent inducers of HIV-1 replication in macrophages (reviewed in reference 51). We therefore investigated whether TNF- $\alpha$ and IL-1 $\beta$ are involved in HIV-1 production induced by LPS. sTNF receptors and IL-1ra are specific inhibitors of TNF- $\alpha$ and IL- $1 \beta$, respectively, and were added to cultures of freshly isolated monocytes $2 \mathrm{~h}$ before LPS treatment. LPS-stimulated MDM secreted large amounts of those proinflammatory cytokines, as well as other cytokines such as IFN- $\alpha$ and CC chemokines (Table I). When incubated with sTNF receptors and IL-1ra, LPS-stimulated MDM support T-tropic ELI1 virus replication less efficiently compared with MDM treated with LPS alone (Fig. $3 C$ ), implying that induction of TNF- $\alpha$ and IL-1 $\beta$ production is critically involved in enhancement of HIV-1 replication in LPS-stimulated MDM. Taken together, LPS-induced upregulation of HIV-1 replication in macrophages is mediated by CD14-dependent path-

Table I. Effects of LPS Stimulation on Secretion of Cytokines by $M D M^{*}$

\begin{tabular}{lcc}
\hline & Unstimulated & LPS-stimulated \\
\hline IFN- $\alpha$ & $<25.6 \mathrm{pg} / \mathrm{ml}$ & 52 \\
TFN- $\alpha$ & 95 & 6900 \\
IL-1 $\beta$ & 60 & 940 \\
RANTES & 260 & 2400 \\
MIP-1 $\alpha$ & 450 & 5600 \\
MIP-1 $\beta$ & 310 & 3400 \\
\hline
\end{tabular}

*Freshly isolated monocytes were either unstimulated or stimulated with LPS $(10 \mathrm{ng} / \mathrm{ml})$ for $5 \mathrm{~d}$, and the cell culture supernatants were assayed for concentrations of the indicated cytokines by ELISA (see Methods). 


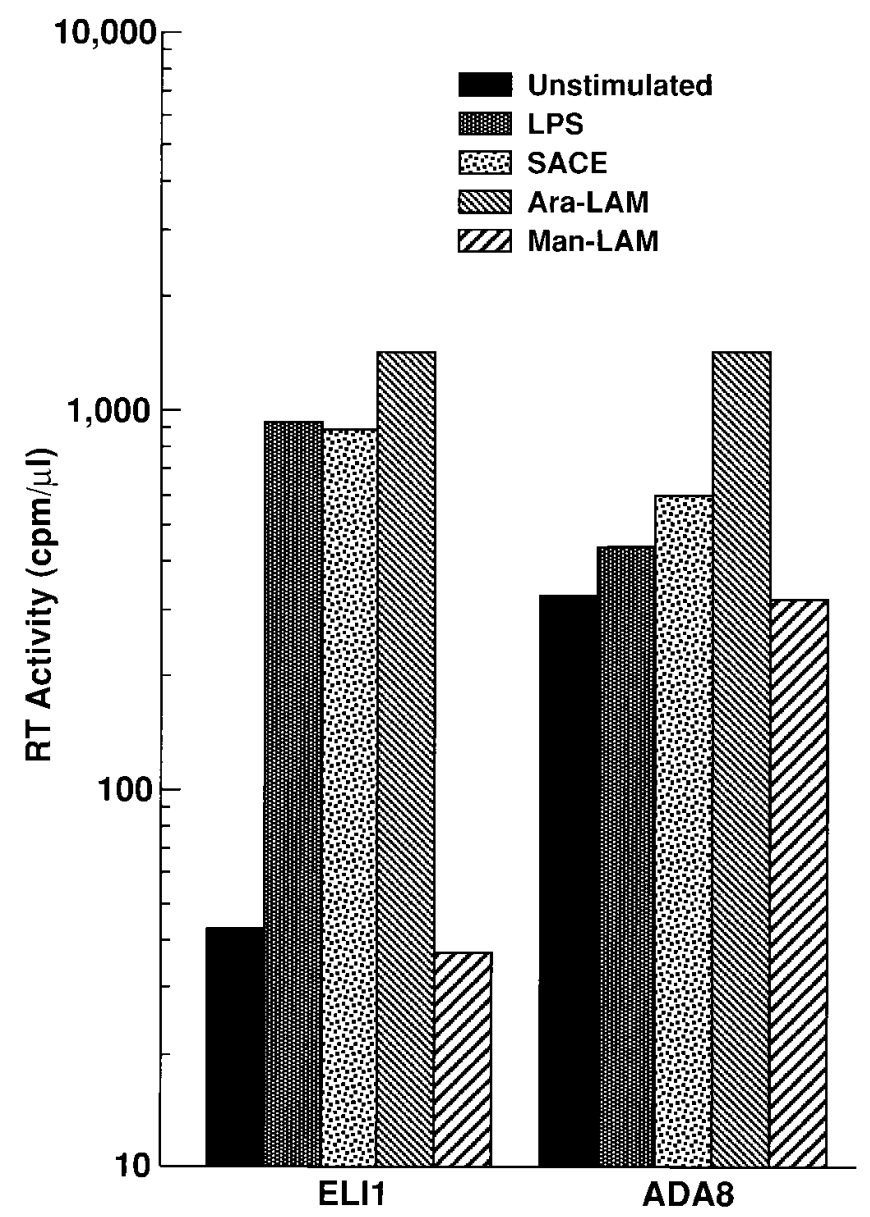

Figure 2. HIV-1 replication in macrophages stimulated with bacterial cell wall components from diverse bacterial species. Freshly isolated monocytes were either unstimulated or stimulated with LPS, SACE, Ara-LAM, or Man-LAM ( $1 \mu \mathrm{g} / \mathrm{ml}$ each) for $7 \mathrm{~d}$ and infected with the indicated molecular clones. The infected culture supernatants were collected every $4 \mathrm{~d}$ for RT assays. Peak titers on day 12 postinfection were shown. Similar results were obtained in two separate experiments.

ways that lead to the activation of PKC and PTK, whose outcomes include, but are not limited to, the activation of expression of proinflammatory cytokines TNF- $\alpha$ and IL-1 $\beta$.

LPS-induced enhancement of HIV replication involves early step $(s)$ in the HIV replication cycle. To investigate at which step(s) in the HIV replication cycle in macrophages LPS exerts its influence, two systems were used. The first is a singleround viral replication assay that uses replication-incompetent luciferase reporter virions pseudotyped by an HIV-1 Env of interest. This assay is useful to monitor efficiency of viral replication during early steps in the replication cycle, from attachment, fusion/entry to early transcription. In this system, infectivity of virus bearing either T-tropic HIV-1 Env (HXB2) or AMV Env was markedly enhanced in LPS-stimulated MDM (Fig. $4 A$ ). In contrast, LPS stimulation had a negligible effect on infectivity of M-tropic Env-bearing virus. However, when the cells were washed to remove the culture supernatants before infection with M-tropic Env-bearing virus, efficiency of virus replication was markedly enhanced, indicating that the supernatants contained soluble factor(s) that suppress rep- lication of M-tropic Env-bearing virus (Fig. $4 A$ ). Removal of the supernatants had less pronounced effects on infection with virus containing T-tropic or AMV Env.

The second system is a fusion assay that exclusively estimates HIV-1 Env-mediated fusogenicity. Fusogenicity of LPSstimulated MDM was only slightly enhanced compared with that of unstimulated MDM with T-tropic HIV-1 Env (HXB2) and modestly, but consistently, reduced with M-tropic HIV-1 Env (Ba-L) (Fig. $4 \mathrm{~B})$. Considering the marked increase in infectivity of T-tropic HIV-1 (Fig. $1 A$ ) and the minimal effect on T-tropic Env-mediated fusogenicity (Fig. $4 B$ ), it is unlikely that LPS-mediated upregulation of T-tropic HIV-1 replication in macrophages is due predominantly to increased fusogenicity of the cells; rather, the upregulation is likely due to the enhancement of postentry early step(s). In this regard, the less pronounced effects of LPS stimulation on M-tropic HIV-1 replication may be due to a dichotomy of reduced fusogenicity and increased infectivity in other step(s) of the viral replicative cycle.

LPS-stimulated macrophages produce soluble factors that positively or negatively regulate HIV infection of macrophages. Experiments described in Fig. $4 \mathrm{~A}$ suggested that the supernatants from LPS-stimulated macrophage cultures contain soluble factors that suppress replication of M-tropic HIV-1. To identify these HIV suppressive factors, crude supernatants were either untreated or subtracted for either of the two well-known HIV suppressive cytokines, IFN- $\alpha$ and CC chemokines (Table II). Untreated supernatants reduced infectability of HIV pseudotyped by any type of Env tested; in contrast, IFN- $\alpha$-subtracted supernatants enhanced their infectability (Fig. 5), indicating that LPS-stimulated macrophages secrete an HIV suppressive factor, IFN- $\alpha$, as well as enhancer(s) of HIV replication. According to data shown in Fig. $3 C$, these enhancers are likely to be the proinflammatory cytokines TNF- $\alpha$ and IL-1 $\beta$. In contrast, subtraction of CC chemokines from the crude supernatants had dichotomous effects. CC chemokinefree supernatants, compared with the untreated supernatants, enhanced infectability of M-tropic HIV-1 but decreased infectability of HIV pseudotyped by T-tropic or amphotropic Env (Fig. 5). Thus, LPS-inducible soluble factors have multiple activities: IFN- $\alpha$ suppress both $\mathrm{M}$ - and T-tropic HIV-1; CC chemokines suppresses M-tropic HIV but enhance T-tropic HIV; and proinflammatory cytokines enhance both viruses.

Table II. Cytokine Concentrations in LPS-conditioned Medium*

\begin{tabular}{lccc}
\hline & Untreated & IFN- $\alpha$ subtracted & $\begin{array}{c}\text { CC chemokine } \\
\text { subtracted }\end{array}$ \\
\hline IFN- $\alpha$ & 60 pg/ml & $<25.6$ & 58 \\
RANTES & 3100 & 3300 & 89 \\
MIP-1 $\alpha$ & 6600 & 5900 & 100 \\
MIP-1 $\beta$ & 4800 & 4100 & $<51.2$
\end{tabular}

*Crude supernatants from LPS-stimulated MDM were treated with either isotype control Igs (untreated), anti-IFN- $\alpha$ antibody (IFN- $\alpha$ subtracted), or antibodies to RANTES, MIP- $1 \alpha$, and MIP- $1 \beta$ in combination (CC chemokine subtracted), followed by protein A/G sepharose, as described in Methods. The concentrations of the indicated cytokines were determined by ELISA. 

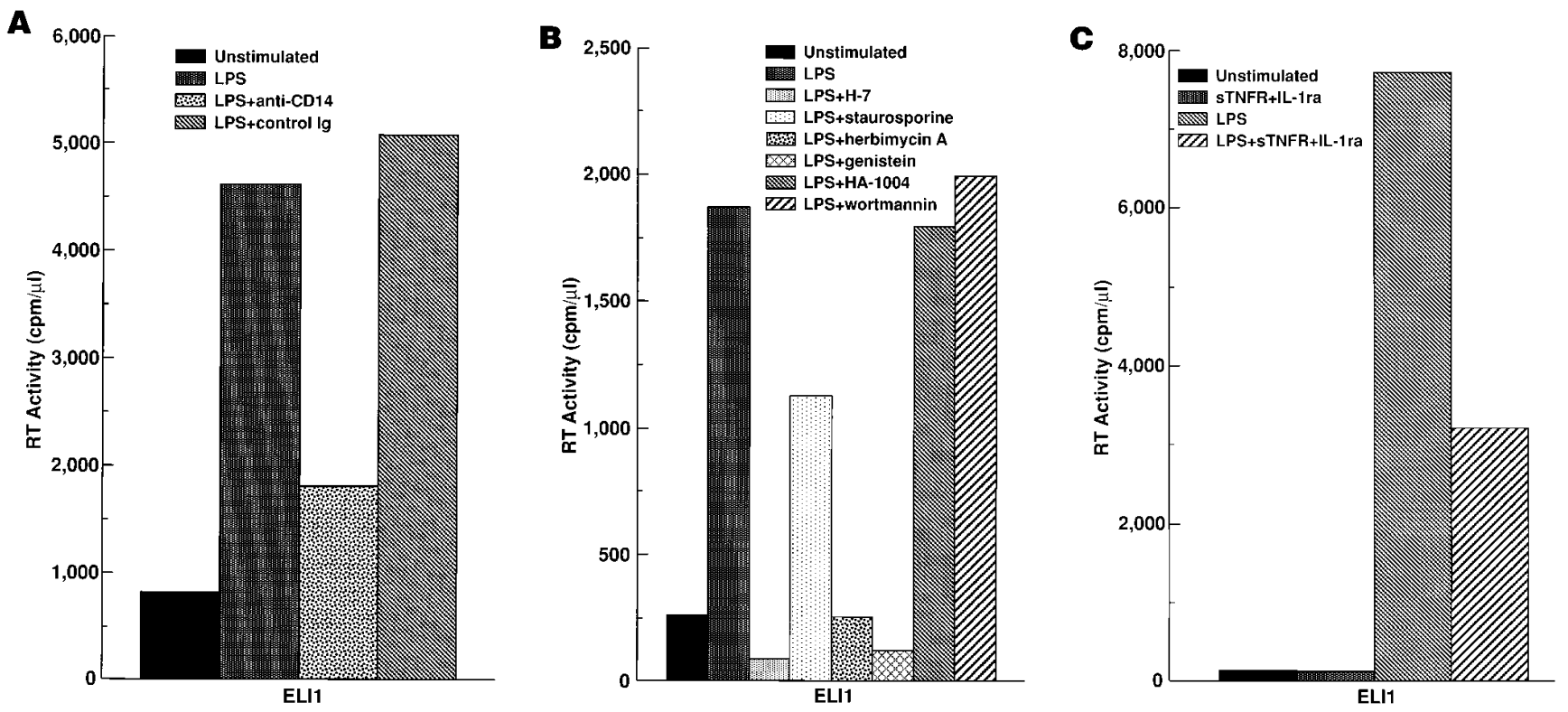

Figure 3. Signaling pathways involved in LPS-mediated effects on HIV-1 replication in macrophages. (A) LPS mediates its effects through CD14. Freshly isolated monocytes were either unstimulated or stimulated with monoclonal anti-CD14 antibody MY-4 or control Ig and then treated with LPS $(10 \mathrm{ng} / \mathrm{ml})$. After $7 \mathrm{~d}$ of incubation, MDM were infected with ELI1 and RT assays were performed for the infected culture supernatants. Peak titers on day 16 postinfection are shown. Results were representative of three independent experiments. $(B)$ LPS mediates its effects via PKC and PTK activities. Freshly isolated monocytes were either untreated or treated with the indicated reagents for $2 \mathrm{~h}$ before LPS $(10 \mathrm{ng} / \mathrm{ml})$ treatment. After $7 \mathrm{~d}$ of incubation, MDM were infected with ELI1, and RT assays were performed for the infected culture supernatants. Peak titers on day 16 postinfection are shown. Results are representative of three independent experiments. $(C)$ LPS mediates its effects, at least in part, by secreting proinflammatory cytokines TNF- $\alpha$ and IL-1 $\beta$. Freshly isolated monocytes were either untreated or treated with sTNFR-I, sTNFR-II, and IL-1ra (100 ng/ml each) for $2 \mathrm{~h}$ before LPS $(10 \mathrm{ng} / \mathrm{ml})$ treatment. After $7 \mathrm{~d}$ of incubation, MDM were infected with ELI1, and RT assays were performed for the infected culture supernatants. Peak titers on day 16 postinfection are shown. Similar results were obtained in two separate experiments.

CCR5 expression is decreased, while CXCR4 expression is increased, in LPS-stimulated macrophages. Fusion assay results suggest that LPS stimulation may favor T-tropic HIV entry but may suppress M-tropic HIV entry to some extent. Since levels of HIV coreceptor expression likely correlate with infectability of HIV-1, we tested whether LPS stimulation regulates expression of CXCR4 (a major coreceptor for T-tropic HIV-1) and CCR5 (a major coreceptor for M-tropic HIV-1). Freshly isolated monocytes expressed barely detectable levels of CCR5 on the cell surface, while CXCR4 expression was abundant. CCR5 expression was increased, while CXCR4 expression was decreased, after 7-d culture in vitro (Fig. 6, $A$ and $B$, top and middle). These results are in agreement with recent publications demonstrating that CXCR4 expression on monocytes is downregulated upon differentiation into mature macrophages (60) and that LPS stimulation downregulates steady state level of CCR5 mRNA (61). LPS-stimulated MDM expressed lower level of CCR5 and higher level of CXCR4 on the cell surface, compared with unstimulated MDM (Fig. 6, $A$ and $B$, middle and bottom). Therefore, taken together with the induction of CC chemokine production, LPS effects on HIV coreceptor expression may result in a decrease in M-tropic HIV-1 entry and a minimal effect on T-tropic HIV-1 entry.

Recent studies have suggested that expression of CCR5 and CXCR4 is differentially regulated in $\mathrm{CD}^{+} \mathrm{T}$ cells $(62,63)$, and we have confirmed some of those results at the level of the coreceptor gene promoter by cloning and characterizing promoter regions for CCR5 (39) and CXCR4 (40). In this regard, regula- tion of HIV coreceptor expression on macrophages by LPS stimulation was further investigated at the level of the coreceptor gene promoter. MDM were transfected with either the CCR5 promoter-luciferase reporter plasmid or the CXCR4 promoter-luciferase reporter plasmid and were either untreated or treated with LPS immediately after transfection. The transfected cells were harvested $3 \mathrm{~d}$ after transfection, and cell lysates were tested for luciferase activity. In agreement with cell surface expression patterns, CCR5 promoter activity was downregulated, while CXCR4 promoter activity was upregulated, by LPS stimulation (Fig. 7). Thus, LPS effects on HIV coreceptor expression were mediated, at least in part, at the level of promoters. We have also demonstrated that LPS stimulation upregulated RANTES promoter activity (Fig. 7). Taken together with the downregulation of CCR5, a receptor for RANTES, these data suggest that LPS stimulation will provide an unfavorable environment for M-tropic HIV-1 entry into macrophages.

\section{Discussion}

Cells of the monocyte/macrophage lineage play critical roles in HIV infection during all stages of disease in that they serve as major target cells, reservoirs, vehicles to other tissues, and transmitters of the virus to $\mathrm{CD}^{+}{ }^{+} \mathrm{T}$ cells. Furthermore, monocyte/macrophage lineage cells are among the first cells to be infected during primary HIV infection (7-10), and are major sources of the virus during opportunistic infections that occur at the advanced stages of HIV disease (2). 
A

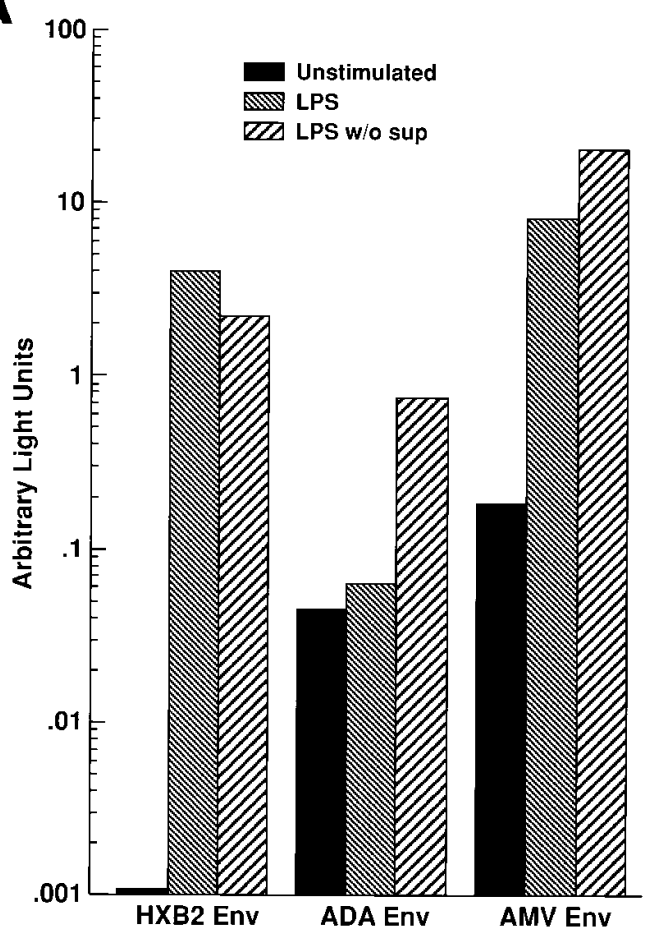

B

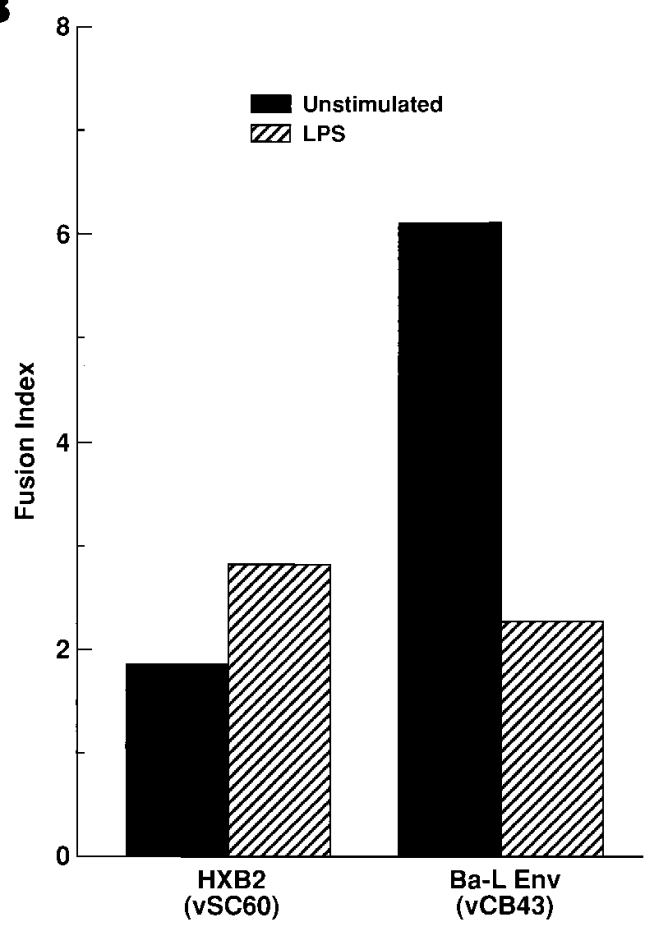

Figure 4. LPS stimulation enhances efficiency of virus infectivity at early stage(s) of the viral replicative cycle. (A) LPS stimulation enhances the efficiency of virus infectivity at early stage(s) of the viral replicative cycle. LPS (10 ng/ml)-stimulated or unstimulated MDM were infected with NL4-3 Luc- $\mathrm{R}^{-} \mathrm{E}^{-}$virus pseudotyped by the indicated Env, and cell lysates were assayed for luciferase activity $4 \mathrm{~d}$ after infection. When infected with the pseudotyped virus, the LPS-stimulated culture supernatants were either removed ( $L P S$ w/o sup) or maintained at a 1:1 ratio of the supernatants and virus inocula $(L P S)$. Results are representative of five independent experiments. $(B)$

LPS stimulation minimally enhances fusogenicity of MDM with T-tropic Env and modestly reduces fusogenicity with M-tropic Env. LPS-stimulated or unstimulated MDM were infected with rVV vTF7-3 (expressing T7 RNA polymerase), while BSC-1 cells were infected with vCB21R (encoding the lac $Z$ gene driven by T7 promoter) and either vCB16 (expressing nonfusogenic mutant HIV-1 Env), vSC60 (expressing HIV-1 HXB2 Env), or vCB43 (expressing HIV-1 Ba-L Env). After overnight culture, MDM (fusion targets) and BSC-1 cells (fusion effectors) were mixed and cell lysates were assayed for $\beta$-galactosidase activity $4 \mathrm{~h}$ after coculture. Fusion index indicates optical density value at $570 \mathrm{~nm}$ for the culture with vSC60 or vCB43 infection relative to that with vCB16 infection. Results are representative of three independent experiments.
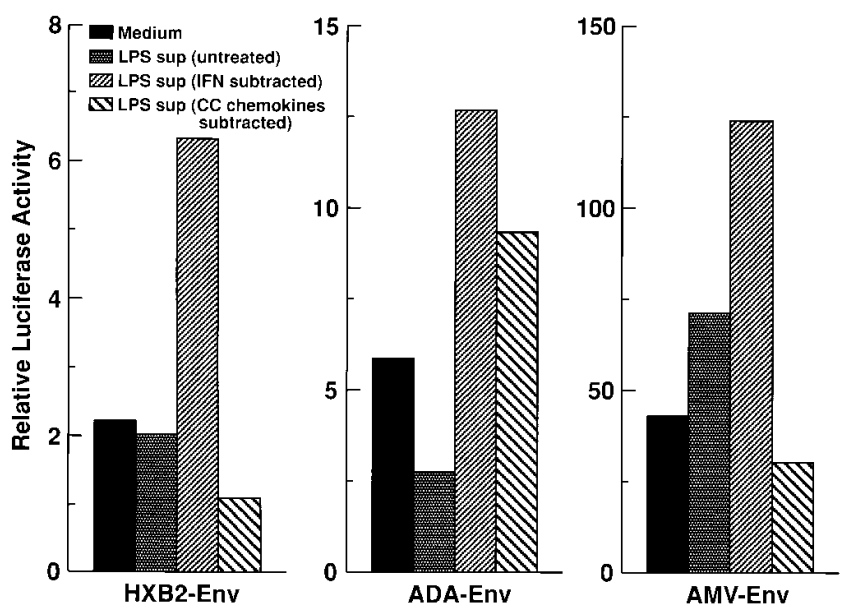

Figure 5. Effects of soluble factors from LPS-stimulated MDM on HIV-1 replication. Freshly isolated monocytes were stimulated with LPS $(10 \mathrm{ng} / \mathrm{ml})$ for $7 \mathrm{~d}$ and pretreated with either fresh medium, crude supernatants from LPS-stimulated MDM cultures, the supernatants subtracted for IFN- $\alpha$, or the supernatants subtracted for RANTES, MIP- $1 \alpha$, and MIP- $1 \beta$ for $1 \mathrm{~h}$ before and throughout infection with NL4-3 Luc- $\mathrm{R}^{-} \mathrm{E}^{-}$virus pseudotyped by the T-tropic HXB2, M-tropic ADA, or amphotropic AMV Env, and cell lysates were assayed for luciferase activity $4 \mathrm{~d}$ after infection. Results are representative of four independent experiments.
HIV variants isolated from individuals in early stage disease replicate well in macrophages as well as in $\mathrm{CD}^{+} \mathrm{T}$ cells but usually lack the capacity to replicate in cells of established $\mathrm{CD}^{+}{ }^{+} \mathrm{T}$ cell lines. However, as disease progresses, the virus tends to lose its capability to efficiently replicate in macrophages and acquires the ability to replicate in established $\mathrm{CD}^{+}{ }^{+} \mathrm{T}$ cell lines. The transition from the former ( $\mathrm{M}$ tropic) to the latter ( $\mathrm{T}$ tropic) phenotype has been associated with disease progression $(6,29,30)$. Since $\mathrm{CD}^{+} \mathrm{T}$ cell numbers are markedly reduced as HIV disease progresses, it remains unclear whether $\mathrm{CD}^{+}{ }^{+} \mathrm{T}$ cells or other cell types serve as major viral reservoirs and sources of plasma viremia during advanced stages of disease. In this regard, a recent study has demonstrated that macrophages are major sources of HIV during opportunistic infections that occur at advanced stages of HIV disease (2). This study implies that microbial coinfections render macrophages highly susceptible to T-tropic HIV-1, which otherwise poorly replicate in macrophages.

In the present study, we tested the abovementioned hypothesis by establishing an in vitro system in which we stimulated MDM with bacterial cell wall components from different species of bacteria to which macrophages are exposed during conventional or opportunistic infections. We have demonstrated that macrophages become highly susceptible to T-tropic HIV-1 and variably susceptible to M-tropic HIV-1 upon stimulation with these bacterial products.

For several years, it has been controversial whether stimulation of macrophages with bacterial LPS inhibits or enhances 
HIV replication. While several studies demonstrated that LPSstimulated macrophages are refractory to HIV infection (20$22)$, others stated the contrary $(18,19)$. In the present study, stimulation with LPS and other bacterial products (SACE and LAM) had dichotomous effects on HIV replication, depending on the virus phenotypes in question, and such outcomes resulted from a delicate balance between HIV enhancing and suppressive factors produced by the stimulated macrophages. While T-tropic HIV-1 infection is almost always enhanced by stimulation of target cells with the bacterial products, the net effect on M-tropic HIV-1 infection varied between experiments. In some experiments, LPS stimulation modestly enhanced M-tropic HIV-1 replication in MDM; however, in other experiments LPS-stimulated MDM were relatively refractory to M-tropic HIV-1 infection. We have observed that LPS stimulation of mature macrophages, as opposed to that of freshly isolated monocytes, conferred resistance to M-tropic HIV-1 more frequently (data not shown), suggesting that levels of cellular activation and/or differentiation may be critical for M-tropic HIV-1 suppression by LPS. Thus, bacterial coinfections may provide a more conducive environment for the replication of T-tropic HIV-1 than for M-tropic HIV-1 in macrophages, thereby favoring a transition from M-tropic to T-tropic viral phenotype.

Several factors are involved in such a dichotomy. First, stimulation with bacterial products activates macrophages through interaction with CD14 and signaling pathways involving PKC and PTK activities. It appears that such activation renders macrophages themselves highly susceptible to HIV-1 infection. Next, the stimulated MDM secrete soluble factors that variably influence HIV replication, including the proinflammatory cytokines TNF- $\alpha$ and IL-1 $\beta$, which favor both M- and T-tropic HIV-1; IFN- $\alpha$, which suppresses both viruses; and CC chemokines RANTES, MIP- $1 \alpha$, and MIP-1 $\beta$, which suppress M-tropic HIV-1 but favor T-tropic HIV-1. Finally, LPS-stimulated MDM express CCR5 (a major coreceptor for M-tropic HIV-1) at lower levels and CXCR4 (a major coreceptor for T-tropic HIV-1) at higher levels than do unstimulated cells. Since factors secreted by LPS-stimulated MDM in aggregate enhance T-tropic HIV-1 replication more than M-tropic HIV-1 replication, the net effect of these factors will likely favor the dominance of T-tropic HIV-1 replication over M-tropic HIV-1 replication. We have recently demonstrated that another microbial coinfection, human T-lymphotropic virus type I, has similar dichotomous effects on HIV infection (64). Therefore, the scenario described above might well be common to a number of other microbial coinfections.

The effects of the CC chemokines on M-tropic HIV-1 infection of macrophages have also been controversial. Several studies have demonstrated that the $\mathrm{CC}$ chemokines have little or no suppressive activity against M-tropic HIV replication in $\operatorname{MDM}(25,31,65)$ or monocytoid cell line (66). Other studies
A
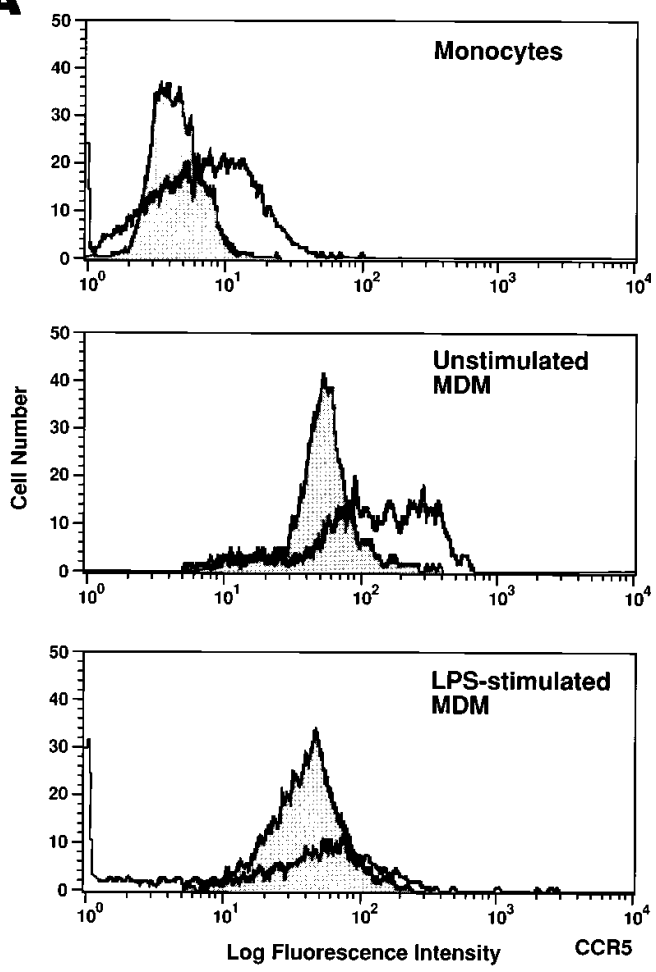

B
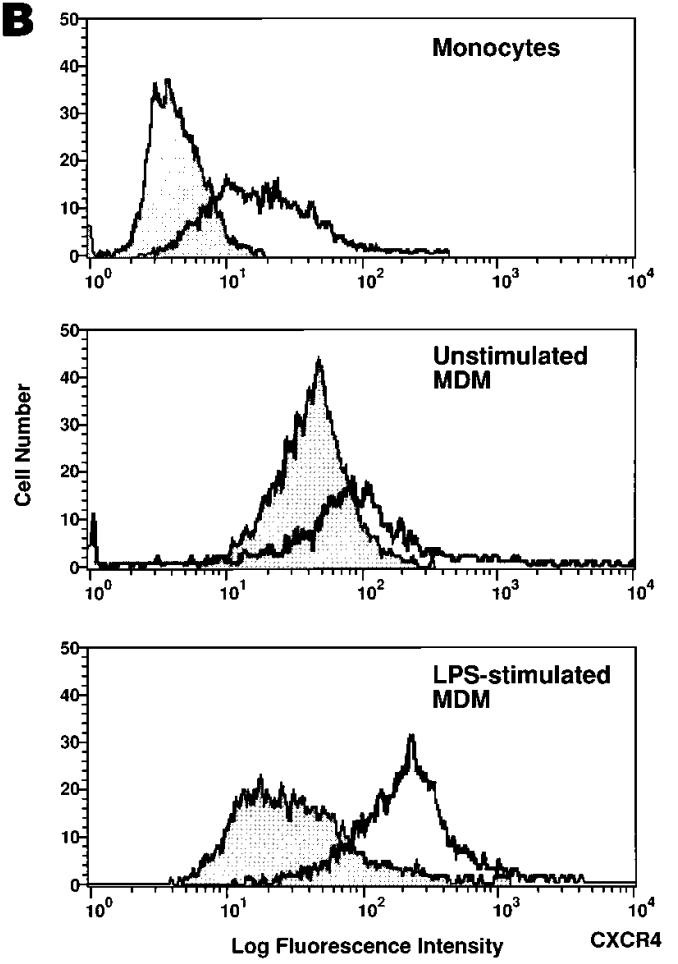

Figure 6. LPS stimulation downregulates cell surface expression of CCR5 and upregulates that of CXCR4. (A) LPS stimulation downregulates cell surface CCR5 expression. Freshly isolated monocytes (top), unstimulated MDM (middle), or MDM stimulated with LPS $(10 \mathrm{ng} / \mathrm{ml})$ for $7 \mathrm{~d}$ (bottom) were stained with either isotype control or 2D7 (anti-CCR5 $\mathrm{mAb}$ ), and analyzed in Cell Quest. Isotype and 2D7 stainings are shown in thick lines with filled and open areas, respectively. (B) LPS stimulation upregulates cell surface CXCR4 expression. Freshly isolated monocytes (top), unstimulated MDM (middle), or MDM stimulated with LPS (10 ng/ml) for $7 \mathrm{~d}$ (bottom) were stained with either isotype control or 12G5 (anti-CXCR4 $\mathrm{mAb}$ ) and analyzed in Cell Quest. Isotype and 12G5 stainings are shown in thick lines with filled and open areas, respectively. 


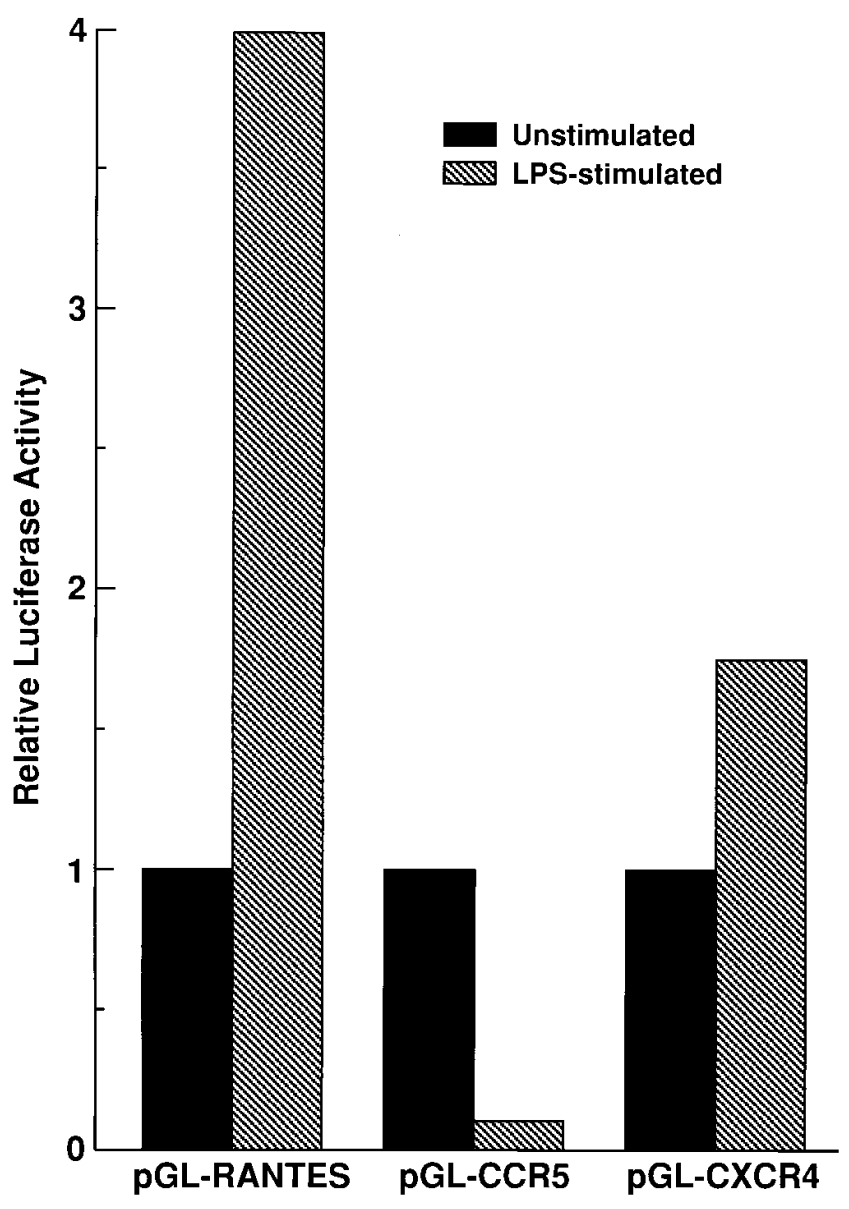

Figure 7. LPS stimulation downregulates CCR5 promoter activity while upregulating CXCR4 promoter activity. Freshly isolated monocytes were plated on 60-mm diameter tissue culture plates and transfected with either pGL-RANTES, pGL-CCR5, or pGL-CXCR4 (15 $\mu \mathrm{g}$ each) on day 3 . The transfected cells were either unstimulated or stimulated with LPS $(10 \mathrm{ng} / \mathrm{ml})$ immediately after transfection and harvested for luciferase assays $3 \mathrm{~d}$ later. Relative luciferase activity was luciferase activity of LPS-stimulated cells relative to that of unstimulated cells. Results are representative of three independent experiments.

have reported that $\mathrm{CC}$ chemokines actually enhance M-tropic HIV replication (67), while still other studies reported that M-tropic HIV infection in MDM is efficiently suppressed by the $\mathrm{CC}$ chemokines $(22,23)$. Potential explanations for the seemingly conflicting data include the possibility that differential propagation and/or stimulation procedures render macrophages sensitive or refractory to the HIV suppressive activity of the $\mathrm{CC}$ chemokines. In this regard, we have found that the CC chemokines suppressed M-tropic HIV replication in LPS-stimulated MDM but not in unstimulated MDM and that the CC chemokines produced by macrophages themselves had much potent HIV suppressive activity than did recombinant CC chemokines (M. Moriuchi, H. Moriuchi, and A.S. Fauci, unpublished observations). Recent studies have suggested that the presence of proteoglycan (68) or posttranslational modification of the CC chemokines (69) greatly influence the ability of the CC chemokines to suppress M-tropic HIV replication in macrophages. Therefore, it is possible that LPS stimulation in- duces critical cellular and molecular events in MDM that influence their susceptibility to the activity of CC chemokines.

It also remains controversial whether replication of T-tropic HIV-1 in macrophages is restricted at a fusion/entry or postentry level. Berger and his colleagues demonstrated that macrophages are fusogenic with M-tropic Env but not with T-tropic Env $(23,70)$, indicating that the major block to T-tropic HIV-1 replication in macrophages is at the step of viral fusion/entry. In contrast, several studies (71-74) have reported that T-tropic HIV-1 efficiently enter macrophages, suggesting that postentry steps are critical for restricted replication of T-tropic HIV-1 in macrophages. The present study demonstrated that stimulation of macrophages with bacterial cell wall components markedly enhanced infectivity of T-tropic HIV-1 and upregulated CXCR4 expression, while having minimal effect on fusogenic activity with T-tropic Env. These results imply that the block of T-tropic HIV-1 replication in macrophages at the step of viral fusion/entry is not absolute, if any, and that stimulation with bacterial cell wall components may release a postentry block of T-tropic HIV infection of macrophages. We are currently investigating the cellular and molecular mechanisms whereby stimulation with bacterial cell wall components releases restriction of T-tropic HIV-1 replication in macrophages.

Our study has a number of implications with regard to the pathogenesis of HIV disease. Enhanced replication of T-tropic HIV-1 in macrophages stimulated by bacteria may explain why macrophages in HIV-infected individuals in the advanced stages of disease (when T-tropic viruses generally predominant) can be major sources of HIV. Furthermore, our study is also compatible with the possibility that individuals infected with bacteria and possibly other microbial pathogens at the time of primary exposure to HIV may acquire T-tropic HIV. Dendritic cells, which belong to macrophage lineage, are thought to be among the first cells to be infected during primary infection, and since they are generally resistant to T-tropic HIV for reasons that remain unclear, M-tropic viruses are selectively transmitted (reviewed in references 75 and 76). However, certain microorganisms, such as those pathogens involved in sexually transmitted diseases, may render macrophages susceptible to T-tropic HIV and allow them to establish primary infection. In this regard, we also have demonstated that macrophages with the homozygous CCR5 mutation, which are highly resistant to both $\mathrm{M}$ - and T-tropic HIV-1 infection (77), become fully susceptible to T-tropic HIV upon LPS stimulation. While individuals homozygous for the CCR5 mutation are highly resistant to HIV infection (78-80), occasional cases of HIV infection in these individuals have been reported (81-83). Our study suggests that transmission of nonCCR5-using, T-tropic variants during primary infection could result from stimulation of cells of the monocyte/macrophage lineage with microbial pathogens.

In conclusion, we have demonstrated that exposure of macrophages to bacterial products variably influences HIV infection in a virus strain-dependent manner and may accelerate a transition from M-tropic to T-tropic phenotype. Further studies will be required to more fully delineate the precise roles of microbial coinfections in the pathogenesis of HIV disease in vivo.

\section{Acknowledgments}

We thank R. Bassin, K. Kassim, S. Tai, E. Vanderpool, M. Hawkins, Jr., and G. Dunston for critical reading; J. Belisle, N. Landau, J. So- 
droski, E. Berger, M. Martin, K. Peden, R. Collman, and T. Theodore for reagents; and J. Weddle for graphic work.

\section{References}

1. Fauci, A.S. 1996. Host factors and the pathogenesis of HIV-induced disease. Nature. 384:529-534.

2. Orenstein, J.M., C. Fox, and S.M. Wahl. 1997. Macrophages as a source of HIV during opportunistic infections. Science. 276:1857-1861.

3. Asjø, B., J. Albert, A. Karlsson, L. Morfeldt-Månson, G. Biberfeld, K. Lidman, and E.M. Fenyø. 1986. Replicative properties of human immunodeficiency virus from patients with varying severity of HIV infection. Lancet. ii: 660-662.

4. Cheng-Mayer, C., D. Seto, M. Tateno, and J.A. Levy. 1988. Biologic features of HIV-1 that correlate with virulence in the host. Science. 240:80-82.

5. Cheng-Mayer, C., T. Shioda, and J.A. Levy. 1991. Host range, replicative, and cytopathic properties of human immunodeficiency virus type 1 are determined by very few amino acid changes in tat and gp120. J. Virol. 65:6931-6941.

6. Connor, R.I., K.E. Sheridan, C. Ceradini, S. Choe, and N.R. Landau. 1997. Change in coreceptor use correlates with disease progression in HIV-1 infected individuals. J. Exp. Med. 185:621-628.

7. Fiore, J.R., A. Bjorndal, K. Aperia-Peike, M. Di Stefano, G. Angarano, G. Pastre, H. Gaines, E.M. Fenyo, and J. Albert. 1994. The biological phenotype of HIV-1 retained during and after sexual transmission. Virology. 204:297303.

8. Scarlatti, G., V. Hodara, P. Rossi, L. Muggiassca, A. Bucceri, J. Albert, and E.M. Fenyo. 1993. Transmission of human immunodeficiency virus type 1 (HIV-1) from mother to child correlates with viral phenotype. Virology. 197: 624-629.

9. van't Wout, A.B., N.A. Kootstra, G.A. Mulder-Kampinga, N. Albrectvan Lent, H.J. Scherpbier, J. Veenstra, K. Boer, R.A. Coutinho, F. Miedema, and H. Schuitemaker. 1994. Macrophage-tropic variants initiate human immunodeficiency virus type 1 infection after sexual, parental, and vertical transmission. J. Clin. Invest. 94:2060-2067.

10. Zhu, T., H. Mo, N. Wang, D.S. Nam, Y. Cao, R.A. Koup, and D.D. Ho. 1993. Genotypic and phenotypic characterization of HIV-1 patients with primary infection. Science. 261:1179-1181.

11. Wahl, S.M., and J.M. Orenstein. 1997. Immune stimulation and HIV-1 viral replication. J. Leukoc. Biol. 62:67-71.

12. Ensoli, B., P. Lusso, F. Schachter, S.F. Josephs, J. Rappaport, F. Negro, R.C. Gallo, and F. Wong-Staal. 1989. Human herpes virus-6 increases HIV-1 expression in co-infected T cells via nuclear factors binding to the HIV-1 enhancer. EMBO J. 8:3019-3027.

13. Gendelman, H.E., W. Phelps, L. Feigenbaum, J.M. Ostrove, A. Adachi, P.M. Howley, G. Khoury, H.S. Ginsberg, and M.A. Martin. 1986. Trans-activation of the human immunodeficiency virus long terminal repeat sequence by DNA viruses. Proc. Natl. Acad. Sci. USA. 83:9759-9763.

14. Scala, G., I. Quinto, M.R. Ruocco, M. Mallardo, C. Ambrosino, B. Squitieri, P. Tassone, and S. Venuta. 1993. Epstein-Barr virus nuclear antigen 2 transactivates the long terminal repeat of human immunodeficiency virus type 1. J. Virol. 67:2853-2861.

15. Siekevitz, M., S.F. Josephs, M. Dukovich, N. Peffer, F. Wong-Staal, and W.R. Greene. 1987. Activation of the HIV-1 LTR by T cell mitogens and transactivator protein of HTLV-I. Science. 238:1575-1578.

16. Lederman, M.M., D.L. Georges, D.J. Kusner, P. Mudido, C.-Z. Giam, and Z. Toossi. 1994. Mycobacterium tuberculosis and its purified protein derivative activate expression of the human immunodeficiency virus. J. Acquir. Immune Defic. Syndr. 7:727-733.

17. Gazzinelli, R.T., A. Sher, A. Cheever, S. Gerstberger, M.A. Martin, and P. Dickie. 1996. Infection of human immunodeficiency virus 1 transgenic mice with Toxoplasma gondii stimulates proviral transcription in macrophages in vivo. J. Exp. Med. 183:1645-1655.

18. Bagasra, O., S.D. Wright, T. Seshamma, J.W. Oakes, and R.J. Pomerantz. 1992. CD14 is involved in control of human immunodeficiency virus type 1 expression in latently infected cells by lipopolysaccharide. Proc. Natl. Acad. Sci. USA. 89:6285-6289.

19. Pomerantz, R.J., M.B. Feinberg, D. Trono, and D. Baltimore. 1990. Lipopolysaccharide is a potent monocyte/macrophage-specific stimulator of human immunodeficiency virus type 1 expression. J. Exp. Med. 172:253-261.

20. Bernstein, M.S., S.E. Tong-Starksen, and R.M. Locksley. 1991. Activation of human monocyte-derived macrophages with lipopolysaccharide decreases human immunodeficiency virus replication in vitro at the level of gene expression. J. Clin. Invest. 88:540-545.

21. Kornbluth, R.S., P.S. Oh, J.R. Munis, P.H. Cleveland, and D.D. Richman. 1989. Interferons and bacterial lipopolysaccharide protect macrophages from productive infection by human immunodeficiency virus in vitro. J. Exp. Med. 169:1137-1151.

22. Verani, A., G. Scarlatti, M. Comar, E. Tresoldi, S. Polo, M. Giacca, P. Lusso, A.G. Siccardi, and D. Vercelli. 1997. C-C chemokines released by lipopolysaccharide (LPS)-stimulated human macrophages suppress HIV-1 infec- tion in both macrophages and T cells. J. Exp. Med. 185:805-816.

23. Alkhatib, G., C. Combadiere, C.C. Broder, Y. Feng, P.E. Kennedy, P.M. Murphy, and E.A. Berger. 1996. CC CKR5: a RANTES, MIP-1 $\alpha$, MIP-1 $\beta$ receptor as a fusion cofactor for macrophage-tropic HIV-1. Science. 272:19551958.

24. Choe, H., M. Farzan, Y. Sun, N. Sullivan, B. Rollins, P.D. Ponath, L. Wu, C.R. Mackay, G. LaRosa, W. Newman, et al. 1996. The $\beta$-chemokine receptors CCR3 and CCR5 facilitate infection by primary HIV-1 isolates. Cell. 85:1135-1148.

25. Deng, D., R. Liu, W. Ellmeier, S. Choe, D. Unutmaz, M. Burkhart, P. DiMarzio, S. Marmon, R.E. Sutton, C.M. Hill, et al. 1996. Identification of a major co-receptor for primary isolates of HIV-1. Nature. 381:661-666.

26. Doranz, B.J., J. Rucker, Y. Yi, R.J. Smyth, M. Samson, S.C. Peiper, M. Parmentier, R.G. Collman, and R.W. Dom. 1996. A dual-tropic primary HIV-1 isolate that uses Fusin and the $\beta$-chemokine receptors CKR-5, CKR-3, and CKR-2b as fusion cofactors. Cell. 85:1149-1158.

27. Dragic, T., V. Litwin, G.P. Allaway, S.R. Martin, Y. Huang, K.A. Nagashima, C. Cayanan, P.J. Maddon, R.A. Koup, J.P. Moore, et al. 1996. HIV-1 entry into $\mathrm{CD}^{+}$cells is mediated by the chemokine receptor CC-CKR-5. $\mathrm{Na}$ ture. 381:667-673.

28. Feng, Y., C. Broder, P.E. Kennedy, and E.A. Berger. 1996. HIV-1 entry cofactor: functional cDNA cloning of a seven-transmembrane $\mathrm{G}$ protein-coupled receptor. Science. 272:872-877.

29. Tersmette, M., R.E.Y. Goede, B.J.M. Al, I.N. Winkler, R.A. Cuypers, H.T. Huisman, and F. Miedema. 1988. Differential syncytium-inducing capacity of human immunodeficiency virus isolates: frequent detection of syncytiuminducing isolates in patients with acquired immunodeficiency syndrome (AIDS) and AIDS-related complex. J. Virol. 62:2026-2032.

30. Tersmette, M., R.A. Gruters, F. De Wolf, R.E.Y. De Goede, J.M.A. Lange, P.T.A. Schellekens, J. Goudsmit, H.G. Huisman, and F. Miedema. 1989. Evidence for a role of virulent human immunodeficiency virus (HIV) variants in the pathogenesis of acquired immunodeficiency syndrome: studies on sequential HIV isolates. J. Virol. 63:2118-2125.

31. Moriuchi, H., M. Moriuchi, C. Combadiere, P.M. Murphy, and A.S Fauci. 1996. $\mathrm{CD}^{+}$T-cell-derived factor(s), but not $\beta$-chemokines RANTES, MIP-1 $\alpha$, and MIP-1 $\beta$, suppress HIV-1 replication in monocyte/macrophages. Proc. Natl. Acad. Sci. USA. 93:15341-15345.

32. Adachi, A., H.E. Gendelman, S. Koenig, T. Folks, R. Willey, A. Rabson, and M.A. Martin. 1986. Production of acquired immunodeficiency syndrome-associated retrovirus in human and non-human cells transfected with an infectious molecular clone. J. Virol. 59:284-291.

33. Peden, K.W.C., and M.A. Martin. 1995. Virological and molecular genetic techniques for studies of established HIV isolates. In HIV. A Practica Approach. Vol. 1. Virology and Immunology. J. Karn, editor. Oxford University Press, Oxford, UK.

34. Collman, R., J.W. Balliet, S.A. Gregory, H. Fiedman, D.L. Kolson, N. Nathanson, and A. Srinivasan. 1992. An infectious molecular clone of unusual macrophage-tropic and highly cytopathic strain of human immunodeficiency virus type 1.J. Virol. 66:7517-7521.

35. Theodore, T.S., G. Englund, A. Buckler-White, C.E. Buckler, M.A. Martin, and K.W. Peden. 1996. Construction and characterization of a stablefull-length macrophage-tropic HIV type 1 molecular clone that directs the production of high titers of progeny virions. AIDS Res. Hum. Retroviruses. 12:191194

36. Moriuchi, H., M. Moriuchi, J. Arthos, J. Hoxie, and A.S. Fauci. 1997a. Promonocytic U937 subclones expressing CD4 and CXCR4 are resistant to infection with and cell-to-cell fusion by T-cell-tropic human immunodeficiency virus type 1. J. Virol. 71:9664-9671.

37. Kusunoki, T., E. Hailman, T.S.-C. Juan, H.S. Lichenstein, and S.D. Wright. 1995. Molecules from Staphylococcus aureus that bind CD14 and stimulate innate immune responses. J. Exp. Med. 182:1673-1682.

38. Moriuchi, H., M. Moriuchi, and A.S. Fauci. 1997b. NF-кB potently upregulates the promoter activity of RANTES, a chemokine that blocks HIV infection. J. Immunol. 158:3483-3491.

39. Moriuchi, H., M. Moriuchi, and A.S. Fauci. 1997c. Cloning and analysis of the promoter region of CCR5, a coreceptor for HIV-1 entry. J. Immunol. 159:5441-5449.

40. Moriuchi, M., H. Moriuchi, W. Turner, and A.S. Fauci. 1997d. Cloning and analysis of the promoter region of CXCR4, a coreceptor for HIV-1 entry. $J$. Immunol. 159:4322-4329.

41. Moriuchi, M., H. Moriuchi, S.E. Straus, and J.I. Cohen. 1994. Varicellazoster virus (VZV) virion-associated transactivator open reading frame 62 protein enhances the infectivity of VZV DNA. Virology. 200:297-300.

42. Gendelman, H.E. J.M. Orenstein, M.A. Martin, C. Ferrua, R. Mitra, T. Phipps, L.A. Wahl, H.C. Lane, A.S. Fauci, D.S. Burke, et al. 1988. Efficient isolation and propagation of human immunodeficiency virus on recombinant colony-stimulating factor 1-treated monocytes. J. Exp. Med. 167:1428-1441.

43. Schuitemaker, H., N.A. Koostar, R.E.Y. De Goede, F. De Wolf, F. Miedema, and M. Tersmette. 1991. Monocytotropic human immunodeficiency virus type 1 (HIV-1) variants detectable in all stages of HIV-1 infection lack T-cell line tropism and syncytium-inducing ability in primary T-cell culture. $J$. Virol. 65:356-363. 
44. Fouchier, R.A.M., M. Brouwer, N.A. Koostra, H.G. Huisman, and H. Schuitemaker. 1994. HIV-1 macrophage tropism is determined at multiple levels of the viral replication cycle. J. Clin. Invest. 94:1806-1814.

45. Valentin, A., J. Albert, E.M. Fenyo, and B. Asjo. 1994. Dual tropism for macrophages and lymphocytes is a common feature of primary human immunodeficiency virus type 1 and 2 isolates. J. Virol. 68:6684-6689.

46. Stent, G., G.-B. Joe, P. Kierulf, and B. Asjo. 1997. Macrophage tropism: fact or fiction? J. Leukocyte Biol. 62:4-11.

47. Roach, T.I.A., C.H. Barton, D. Chatterjee, and J.M. Blackwell. 1993. Macrophage activation: lipoarabinomannan (LAM) from avirulent and virulent strains of Mycobacterium tuberculosis differently induces the early genes c-fos, KC, JE, and TNF- $\alpha$. J. Immunol. 150:1886.

48. Roach, T.I.A., C.H. Barton, F.Y. Liew, and J.M. Blackwell. 1995. Opposing effects of interferon- $\gamma$ on iNOS and interleukin-10 expression in lipopolysaccharide- and mycobacterial lipoarabinomannan-stimulated macrophages. Immunology. 85:106-113.

49. Pugin, J., D. Heumann, A. Tomasz, V.V. Kravchenko, Y. Akamatsu, M. Nishijima, M.P. Glauser, P.S. Tobias, and R.J. Ulevitch. 1994. CD14 is a pattern recognition receptor. Immunity. 1:509-516.

50. Reiner, N.E. 1994. Altered cell signaling and mononuclear phagocyte deactivation during intracellular infection. Immunol. Today. 15:374-381.

51. Poli, G., and A.S. Fauci. 1995. A role of cytokine in the pathogenesis of human immunodeficiency virus infection. In Human Cytokines: Their Role in Disease and Therapy. B. Aggarwahl and R. Puri, editors. Blackwell Science, Cambridge, MA. 421-449.

52. Wright, S.D., R.A. Ramos, P.S. Tobias, R.J. Ulevitch, and J.C. Mathison. 1990. CD14, a receptor for complexes of lipopolysaccharide (LPS) and LPS binding protein. Science. 249:1431.

53. Kitchens, R.L., R.J. Ulevitch, and R.S. Munford. 1992. Lipopolysaccharide (LPS) partial structures inhibit responses to LPS in a human macrophage cell line without inhibiting LPS uptake by a CD14-mediated pathway. J. Exp. Med. 176:485.

54. Couturier, C., G. Jahns, M.D. Kazatchkine, and N. Haeffner-Cavaillon. 1992. Membrane molecules which trigger the production of interleukin-1 and tumor necrosis factor- $\alpha$ by lipopolysaccharide-stimulated human monocytes. Eur. J. Immunol. 22:1461.

55. Uehara, Y., and H. Fukazawa. 1991. Use and selectivity of herbimycin A as inhibitor of protein tyrosine kinases. In Methods in Enzymology. Vol. 201B. T. Hunter and B.M. Sefton, editors. Academic Press, London. 370-379.

56. Mustelin, T., K.M. Coggeshall, N. Isakov, and A. Altman. 1990. T cell antigen receptor mediated activation of phospholipase $\mathrm{C}$ requires tyrosine phosphorylation. Science. 247:1584

57. Hidakad, H., M. Inagaki, S. Kawamoto, and Y. Sasaki. 1984. Isoquinolinesulfonamides, novel and potent inhibitors of cyclic nucleotide dependent protein kinase and protein kinase C. Biochemistry. 23:5036-5041.

58. Arcaro, A., and M.P. Wymann. 1993. Wortmannin is a potent phosphatidylinositol 3-kinase inhibitor: the role of phosphatidylinositol 3,4,5-triphosphate in neutrophil responses. Biochem. J. 296:297-301.

59. Shapira, L., S. Takashiba, C. Champagne, S. Amar, and T.E. Van Dyke. 1994. Involvement of protein kinase $\mathrm{C}$ and protein tyrosine kinase in lipopolysaccharide-induced TNF- $\alpha$ and IL- $1 \beta$ production by human monocytes. J. Immunol. 153:1818-1824.

60. McKnight, A., D. Wilkinson, S. Simmons, S. Talbot, L. Picard, M. Ahuja, M. Marsh, J.A. Hoxie, and P.R. Clapham. 1997. Inhibition of human immunodeficiency virus fusion by a monoclonal antibody to a coreceptor (CXCR4) is both cell type and virus strain dependent. J. Virol. 71:1692-1696.

61. Sica, A., A. Saccani, A. Borsatti, C.A. Power, T.N.C. Wells, W. Luini, N. Polentarutti, S. Sozzani, and A. Mantovani. 1997. Bacterial lipopolysaccharide rapidly inhibits expression of $\mathrm{C}-\mathrm{C}$ chemokine receptors in human monocytes. $J$. Exp. Med. 185:969-974.

62. Bleul, C.C., L. Wu, J.A. Hoxie, T.A. Springer, and C.R. Mackay. 1997. The HIV coreceptors CXCR4 and CCR5 are differently expressed and regulated on human T lymphocytes. Proc. Natl. Acad. Sci. USA. 94:1925-1929.

63. Carroll, R.G., J.L. Riley, B.L. Levine, Y. Feng, S. Kaushal, D.W. Ritchey, W. Bernstein, O.S. Weislow, C.R. Brown, E.A. Berger, et al. 1997. Differential regulation of HIV-1 fusion cofactor expression by CD28 costimulation of $\mathrm{CD}^{+}$T cells. Science. 276:273

64. Moriuchi, H., M. Moriuchi, and A.S. Fauci. 1998. Factors secreted by HTLV-I infected cells can enhance or inhibit replication of HIV-1 in HTLV-I uninfected cells: implications for in vivo coinfection with HTLV-I and HIV-1.J.
Exp. Med. 187:1689-1697.

65. Simmons, G., P.R. Clapham, L. Picard, R.E. Offord, M.M. Rosenkilde, T.W. Schwarts, R. Buser, T.N.C. Wells, and A.E.I. Proudfoot. 1997. Potent inhibition of HIV-1 infectivity in macrophages and lymphocytes by a novel CCR5 antagonist. Science. 276:276-279.

66. Moriuchi, H., M. Moriuchi, and A.S. Fauci. 1998. Differentiation of promonocytic U937 subclones into macrophage-like phenotypes regulates a cellular factor(s) which modulates fusion/entry of macrophage-tropic human immunodeficiency virus type 1. J. Virol. 72:3394-3400.

67. Schmidtmayerova, H., B. Sherry, and M. Bukrinsky. 1996. Chemokines and HIV replication. Nature. 382:767.

68. Wagner, L., O.O. Yang, E.A. Garcia-Zepeda, Y. Ge, S.A. Kalams, B.D Walker, M.S. Pasternack, and A.D. Luster. 1998. $\beta$-Chemokines are released from HIV-1-specific cytotoxic T-cell granules complexed to proteoglycans. $\mathrm{Na}$ ture. 391:908-911.

69. Proost, P., I. De Meester, D. Schols, S. Struyf, A.-M. Lambeir, A. Wuyts, G. Opdenakker, E. De Clercq, S. Scharpe, and J. Van Damme. 1998. Amino-terminal truncation of chemokines by CD26/dipeptidyl-peptidase IV. Conversion of RANTES into a potent inhibitor of monocyte chemotaxis and HIV-1-infection. J. Biol. Chem. 273:7222.

70. Broder, C.C., and E.A. Berger. 1995. Fusogenic selectivity of the envelope glycoprotein is a major determinant of human immunodeficiency virus type 1 tropism for $\mathrm{CD}^{+}$T-cell lines vs. primary macrophages. Proc. Natl. Acad. Sci. USA. 92:9004-9008.

71. Huang, Z.B., M.J. Potash, M. Simm, M. Shahabuddin, W. Chao, H.E. Gendelman, E. Eden, and D.J. Volsky. 1993. Infection of macrophages with lymphotropic human immunodeficiency virus type 1 can be arrested after viral DNA synthesis. J. Virol. 67:6893-6896.

72. Nuovo, G.J., F. Gallery, P. MacConnell, and A. Braun. 1994. In situ detection of polymerase chain reaction-amplified HIV-1 nucleic acids and tumor necrosis factor-alpha RNA in the central nervous system. Am. J. Pathol. 144: 659-666.

73. Schmidtmayerova, H., M. Alfano, G. Nuovo, and M. Bukrinsky. 1998. Human immunodeficiency virus type $1 \mathrm{~T}$-lymphotropic strains enter macrophages via a CD4- and CXCR4-mediated pathway: replication is restricted at a postentry level. J. Virol. 72:4633-4642.

74. Valentin, A., J. Albert, E.M. Fenyo, and B. Asjo. 1994. Dual tropism for macrophages and lymphocytes is a common feature of primary human immunodeficiency virus type 1 and 2 isolates. J. Virol. 68:6684-6689.

75. Weissman, D., and A.S. Fauci. 1997. Role of dendritic cells in immunopathogenesis of human immunodeficiency virus infection. Clin. Microbiol. Rev. 10:358-367.

76. Zambruno, G., A. Gianetti, U. Bertazzoni, and G. Girolomoni. 1995. Langerhans cells and HIV-1 infection. Immunol. Today. 16:520-524.

77. Connor, R.I., W.A. Paxton, K.E. Sheridan, and R.A. Koup. 1996. Macrophages and $\mathrm{CD}^{+}$lymphocytes from two multiply exposed, uninfected individuals resist infection with primary non-syncitium-inducing isolates of human immunodeficiency virus type 1. J. Virol. 70:8758-8764.

78. Liu, R., W.A. Paxton, S. Choe, D. Ceradini, S.R. Martin, R. Horuk, M.E. MacDonald, H. Stuhlmann, R.A. Koup, N.R. Landau. 1996. Homozygous defect in HIV-1 coreceptor accounts for resistance of some multiply-exposed individuals to HIV-1 infection. Cell. 86:367-377.

79. Samson, M., F. Libert, B.J. Doranz, J. Rucker, C. Liesnard, C.M. Farber, S. Saragosti, C. Lapoumeroulie, J. Cognaux, C. Forceille, et al. 1996. Resistance to HIV-1 infection in Caucasian individuals bearing mutant alleles of the CCR-5 chemokine receptor gene. Nature. 382:722-725.

80. Dean, M., M. Carrington, C. Winkler, G.A. Huttley, M.W. Smith, R. Allikmets, J.J. Goedert, S.P. Buchbinder, E. Vittinghoff, E. Gomperts, et al. 1996 Genetic restriction of HIV-1 infection and progression to AIDS by a deletion allele of the CKR5 structural gene. Science. 273:1856-1862.

81. Biti, R., R. French, J. Young, B. Bennetts, and G. Stewart. 1997. HIV-1 infection in an individual homozygous for the CCR5 deletion allele. Nat. Med. 2:1240-1243.

82. O'Brien, T., C. Winkler, M. Dean, J.A. Nelson, M. Currington, N.L. Michael, and G.C. White. 1997. HIV-1 infection in a man homozygous for CCR5 32. Lancet. 349:1219.

83. Theodorou, I., L. Meyer, M. Magierowska, C. Katlama, and C. Rouzioux. 1997. HIV-1 infection in an individual homozygous for CCR5 32 . Lancet. 349: 1219-1220. 